\title{
Ethnomathematic Exploration at Agung Jami' Malang Mosque In Improving Students' Mathematic Problem Solving Ability
}

\author{
Muhammad Hasan Asnawi ${ }^{\star}$ \\ Master of Mathematics Education, State Islamic University of Maulana Malik Ibrahim Malang \\ hasan.asnawi6127@gmail.com

\section{Hurriyatul Annisa} \\ Master of Mathematics Education, State Islamic University of Maulana Malik Ibrahim Malang
}

Moh. Miftakhul Ulum

Master of Mathematics Education, State Islamic University of Maulana Malik Ibrahim Malang

\section{Nur Laili Arofah}

Master of Mathematics Education, State Islamic University of Maulana Malik Ibrahim Malang

\section{Novita Erni Hendrawati}

Master of Mathematics Education, State Islamic University of Maulana Malik Ibrahim Malang

\section{ABSTRACT}

Ethnomathematics has developed and made a major contribution to learning mathematics. One of them is in improving students' mathematical problem solving abilities. The purpose of this study is to explore the ethnomathematics contained in the Agung Jami' Malang Mosque as a means of student learning in improving problem solving skills. The research methods used are ethnography and quantitative. The research instrument is the human instrument, the researcher is directly related to the research, as well as collecting research data through observation, literature, documentation, and tests. In addition, researchers analyzed quantitative data that had been obtained from the results of trials on elementary school students. From the research that has been done, it is found that the ethnomathematics contained in the Agung Jami' Malang Mosque is in the form of geometric shapes, including rectangles, tubes, semi-circles and other geometric shapes. From the results of the trials that have been carried out, it was found that the problem-solving ability of students increased when working on problem-solving problems with the help of ethnomathematics found at the Agung Jami' Malang Mosque.

Keywords: Exploration, Ethnomathematics, problem solving.

\section{ABSTRAK}

Etnomatematika telah berkembang dan memberikan kontribusi besar dalam pembelajaran matematika. Salah satunya dalam meningkatkan kemampuan pemecahan masalah matematis siswa. Tujuan dari penelitian ini yaitu mengeksplorasi etnomatematika yang terdapat pada Masjid Agung Jami' Malang sebagai sarana pembelajaran siswa dalam meningkatkan kemampuan pemecahan masalah. Metode penelitian yag digunakan yaitu etnografi dan kuantitatif. Instrument penelitian ini yaitu human instrument, peneliti berkaitan langsung dengan penelitian, serta sebagai pengumpul data penelitian melalui observasi, pustaka, dokumentasi, dan tes. Selain itu peneliti melakukan analisis data kuantitatif yang telah didapatkan dari hasil uji coba terhadap siswa sekolah dasar. Dari penelitian yang telah dilakukan didapatkan bahwa etnomatematika yang terdapat pada Masjid Agung Jami' Malang berupa bangun-bangun geometri, diantaranya yaitu persegi Panjang, tabung, setengah lingkaran serta bangun geometri lainnya. Dari hasil uji coba yang telah dilaksanakan didapatkan bahwa kemampuan pemecahan masalah siswa meningkat ketika 
mengerjakan soal pemecahan masalah dengan bantuan etnomatematika yang terdapat pada masjid agung jami' kota malang.

Kata Kunci: Eksplorasi, Etnomatematika, pemecahan masalah

\section{INTRODUCTION}

Problem solving is an important part as a learning outcome in the mathematics learning process (Sulasmono, 2017; S. A. Widodo et al., 2020; Widodo et al., 2020; Yuwono, 2016). This can be seen from the many studies on problem solving (Arifin et al., 2010; Nicole R. Rigelman, 2013; Turyanto et al., 2019; Vahlia \& Agustina, 2017; Yuwono, 2016, 2018). Problem solving is a complex activity and a high level of one's mental processes. Problem solving is defined as a combination of bright ideas to form new combinations of ideas, it emphasizes reasoning as the basis for combining ideas and leads to problem solving (Balley, 1989). From this definition it can be concluded that problem solving is a process of thinking about how to solve problems in learning. Therefore, problem solving ability must be owned by each student. But in reality the problem solving ability of students is still lacking, so that the learning outcomes they get are not as expected (Mulyati, 2016; Sumartini, 2016).

The student learning process using problem solving methods can produce new experiences for students by using the experience they already have (Hadi \& Radiyatul, 2014). Student experience is very influential on learning outcomes. Students who only have little experience will have difficulty solving the problems at hand and students who have a lot of experience will have many ideas to solve a problem (Amir, 2015). The experience gained in the learning process is obtained from the daily lives of students. In everyday life, students cannot be separated from the culture and customs that exist in the environment. Thus, the learning process and culture are two things that cannot be separated from students' lives (Wahyuni et al., 2013).

The culture that exists in the community has an influence on the educational process in schools (Sumarni, 2018). Schools that are in an Islamic environment will create an Islamic environment. Thus, students have a better understanding of Islam. The mosque is one place that has an important role in the spread of Islamic education (Hairunnizam Wahid et al., 2009). Almost all religious knowledge is taught in the mosque area, so that people really understand the importance of the mosque's existence in its environment. Every student who studies in the mosque environment will know the parts of the building that are in the mosque.

In Malang, one of the famous mosques is the Agung Jami' Malang Mosque. This mosque was built in $1875 \mathrm{AD}$. This mosque is located in the city center, precisely in front of the Malang square. The strategic location of the mosque makes the mosque never empty of worshipers. Both pilgrims from the community around the mosque and people who travel in the city square. The form of building a mosque that uses a lot of concepts can be used as a medium for student learning, so that students are easy to understand the subject matter given. In this study, researchers conducted research on "Improving students' skills in solving mathematical problems through ethnomathematics at the Agung Jami' Malang Mosque".

14 Muhammad H. Asnawi, Hurriyatul Annisa, Moh. M. Ulum, Nur L. Arofah, and Novita E. Hendrawti Ethnomathematic Exploration at Agung Jami' Malang Mosque In Improving Students' Mathematic Problem Solving Skill 


\section{METHOD}

This research is a type of research using a fixed method approach with ethnographic and quantitative research types. The purpose of this study is to describe the ethnomathematics found in the Agung Jami' Malang Mosque and to apply ethnomathematics in solving mathematical problems. then analyzed quantitatively to determine students' mathematical problem solving abilities. The presence of researchers in this study is as the main instrument. Data collection techniques through observation, References, documentation, and tests. The data collection tools used are cellphones and problem solving questions.

The study began by collecting field data with direct observation at the Agung Jami' Malang Mosque. After that, analyze the data obtained during observation, and make mathematical problem solving problems through ethnomathematics. Problem solving questions are given to elementary school students. Before students are given problem solving questions, a pre-test is carried out first. Then students are given learning with the help of ethnomathematics about the material of geometry. At the end of the lesson, students were given a post-test about problem solving.

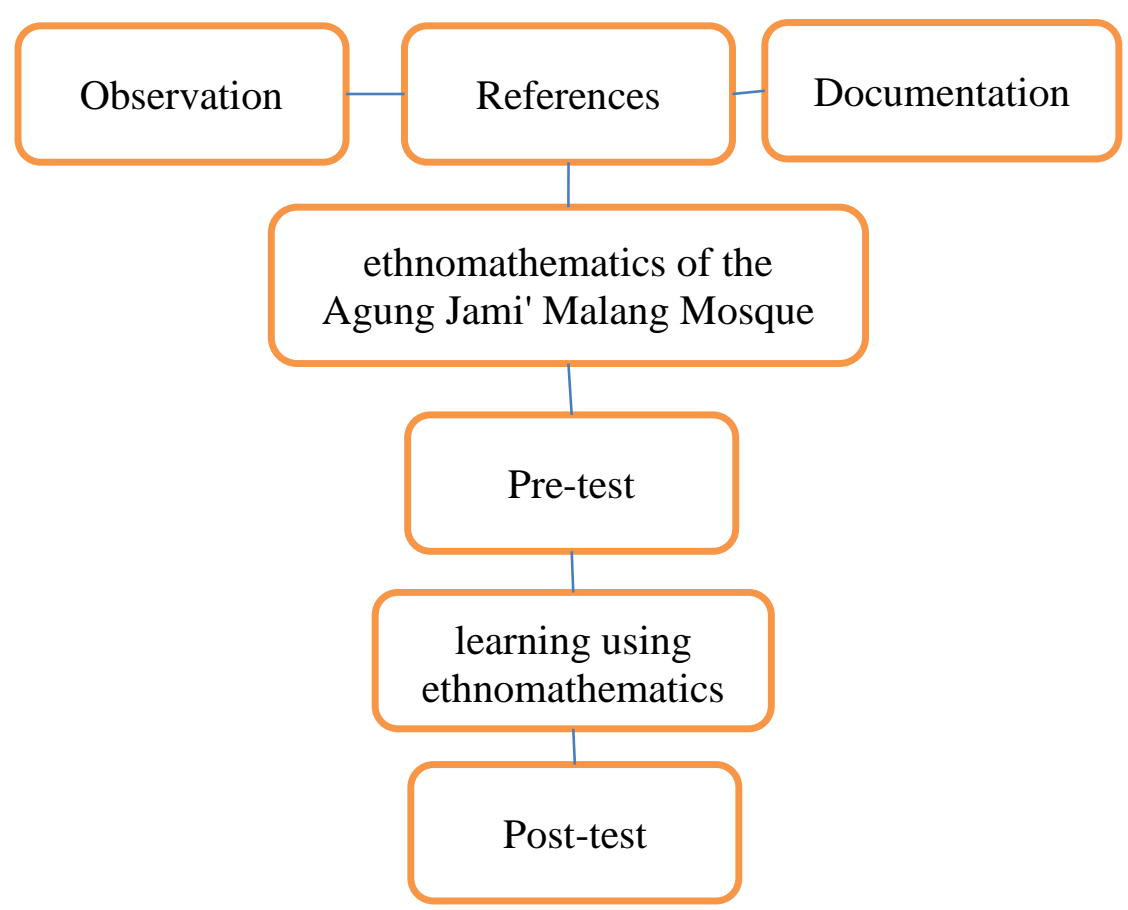

Figure 1. Research Design

\section{RESULT AND DISCUSSION}

\section{Agung Jami' Malang Mosque}

The sociological understanding of the mosque, which developed in Indonesian Islamic society, is understood as a certain place or building intended for Muslims to pray, which consists of obligatory prayers and sunnah prayers, either individually or in congregation. It is also intended to carry out other worship services and perform Friday prayers. In subsequent developments, the mosque is understood as a place used for the caretaker prayers and Friday prayers, which are often called jami' or jami' mosques. Meanwhile, buildings similar to mosques that are used for obligatory and sunnah 
prayers, which are not used for Friday prayers are called "mushalla". This word denotes the food name of "shalla" - "yushalli" - "shalatan" which means a place of prayer. From the above understanding it can be understood that every mosque also means a prayer room, but not every prayer room is a mosque. The prayer room is often called by the name of tajug, langgar, surau, and meunasah (Muslim, 2004).

The Agung Jami' Malang mosque was founded in 1890 AD on state land of about 3,000 m2. According to the existing inscription, the Agung jami' mosque was built in two stages. The first phase was built in $1875 \mathrm{AD}$, then the second phase began on March 15, 1903, and was completed on September 13,1903 . The mosque building is a rectangular steel structure with a double-sided roof, and until now the original building is still maintained (Mahmudi, n.d.; Ramdlani, 2010).

Judging from its shape, Agung Jami' Malang Mosque has two architectural styles, namely Javanese architecture and Arabic architecture. The Javanese architectural style can be seen from the shape of the roof of the old mosque in the form of a tajug. While the Arabic architectural style can be seen from the shape of the dome on the minaret of the mosque and also the curved construction of the openings (doors and windows) (Mahmudi, n.d.; Ramdlani, 2010).

\section{Ethnomathematics of the Agung jami' Malang Mosque}

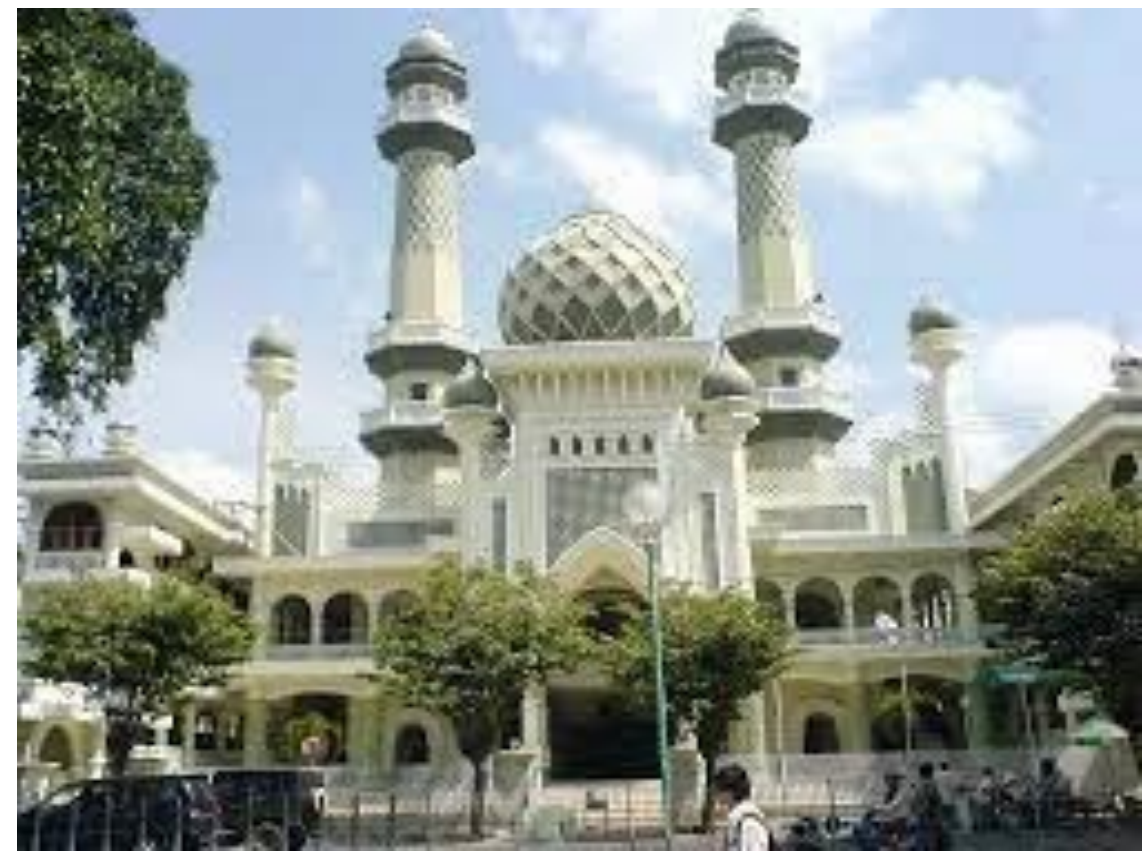

Figure 2. The Agung Jami' Malang Mosque Front look

From the observations obtained, there is an explanation of the history of the Agung Jami' Malang Mosque. The Agung Jami' Malang Mosque was built in 1875 AD the Agung Jami' Malang Mosque is included in one of the three lucky mosques of East Java, namely the Ampel Mosque in Surabaya and the Jami' Pasuruan Mosque which in Javanese is known as "beryoni". This mosque has 20 pillars, as a symbol of the 20 mandatory attributes of Allah. and 4 large pillars in front as a symbol of the 4 attributes of the Prophet Muhammad. 
The pillars of the mosque are the main place to indulge prayers to Allah SWT. "Currently I am small, KH. Zaini Amin once told about the primacy of the pillars of the mosque, because when it was built the founders fasted solemnly, to the point that after Friday prayers the mosque elders scrambled to lean on these pillars while offering praise to Allah SWT." (KH. Kamilun, Chairman of the Jami' Mosque Foundation). In ancient times inside the mosque there was an inscription containing the inauguration of the expansion of the mosque which began on March 15, 1903 and finished September 13, 1903. The inscription was signed directly by the Regent of Malang IV, Raden Bagoes Mohamad Sarib who became the Regent of Malang with the title Raden Adipati Ario Soerio Adiningrat, served from 1898 to 1934 . The second expansion in 1950, the third in 1980, the fourth in 1992 and in 2002 at the suggestion of a French architect who observed the condition of the building firsthand, this mosque was strengthened and beautified until now. The shape and ornament of the mosque has been maintained "Njawani" until now where you can see the shape of the door, ornate spears and carvings of iron and steel since it was first built.

After doing the observations, it was found that several forms of buildings have mathematical aspects so that they can be used as learning media. Table 1 is an ethnomathematical identification at the Agung Jami' Malang Mosque

Table 1. identification at the Agung Jami' Malang Mosque

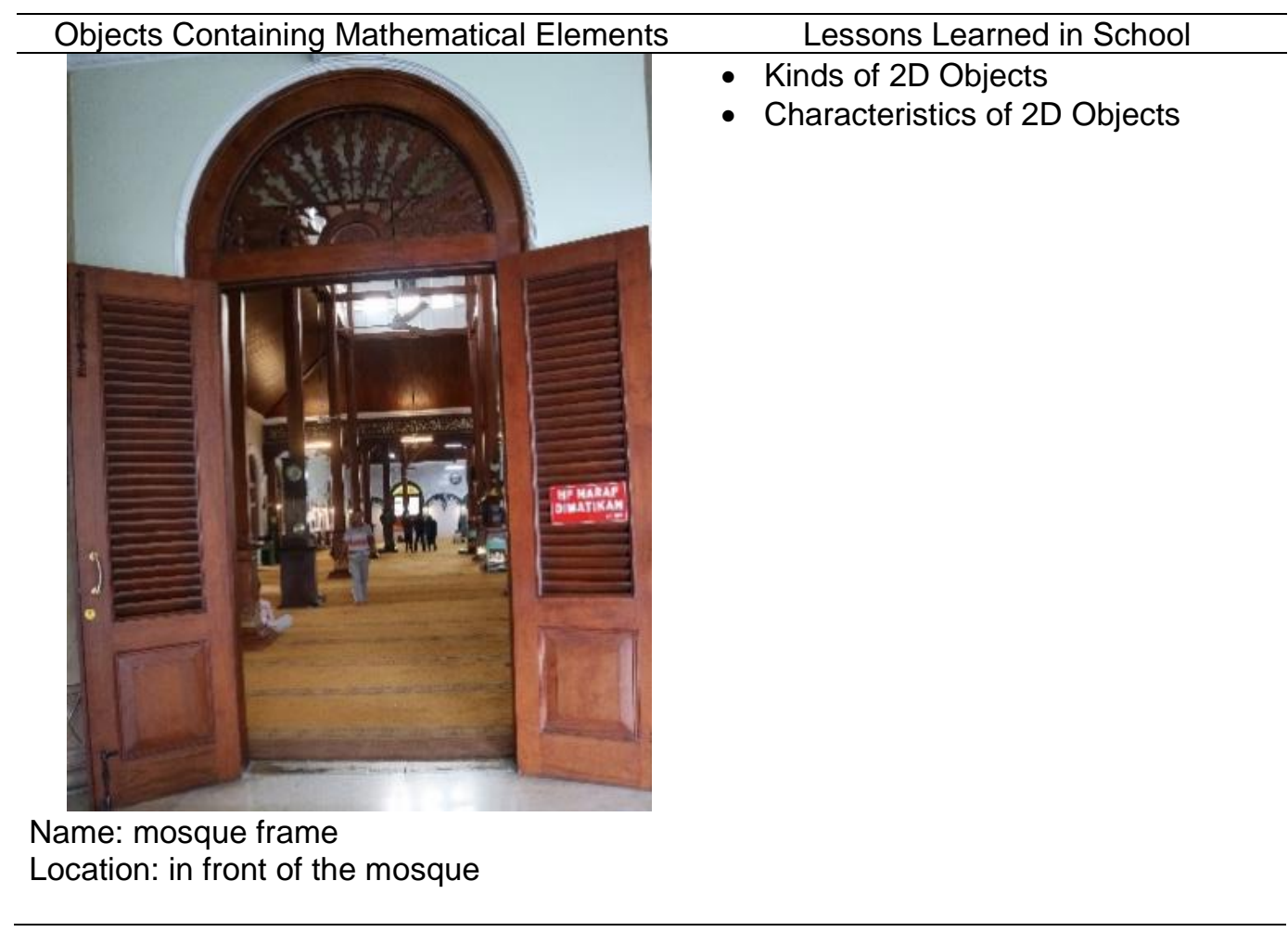



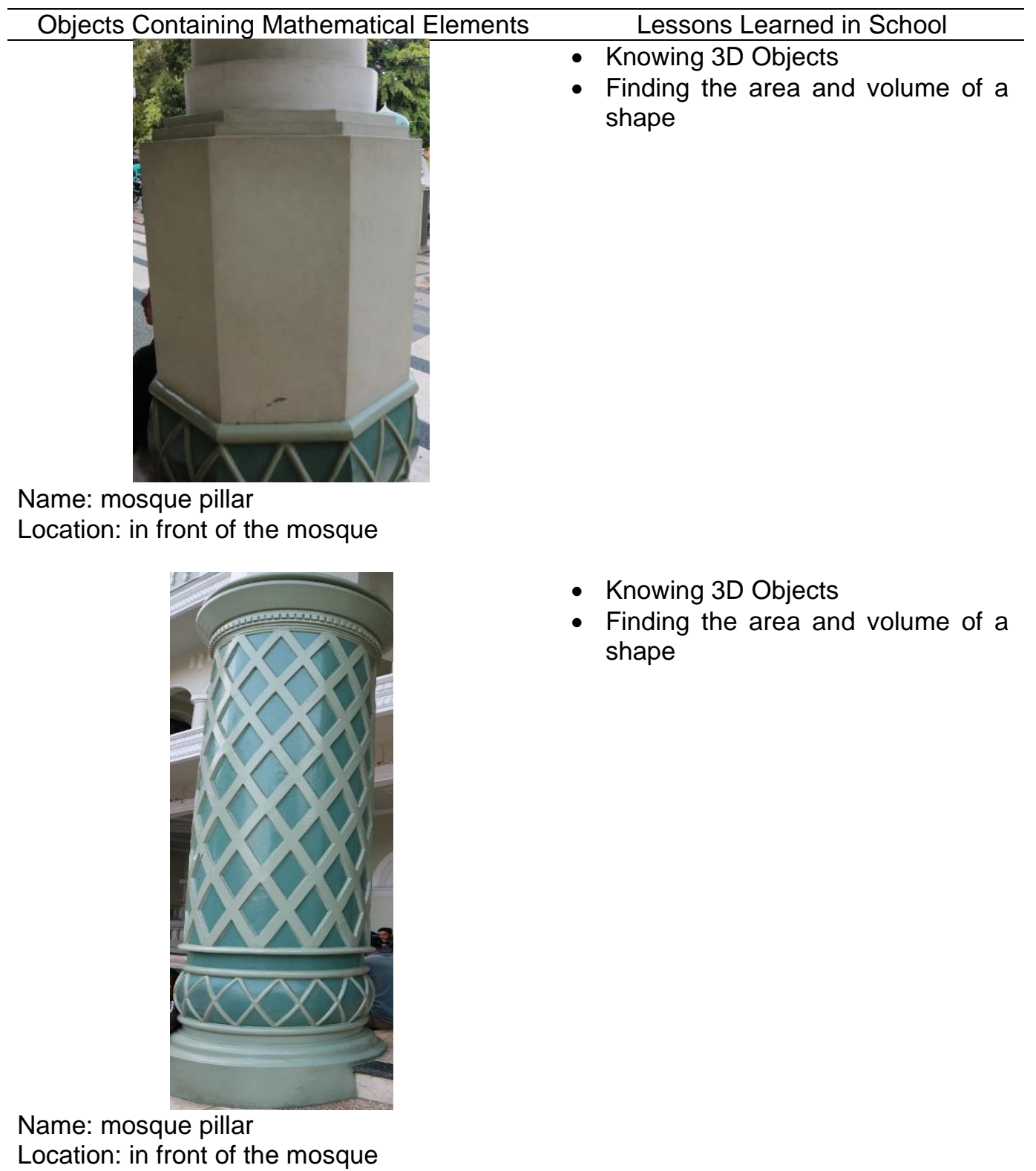

- Knowing 2D Objects

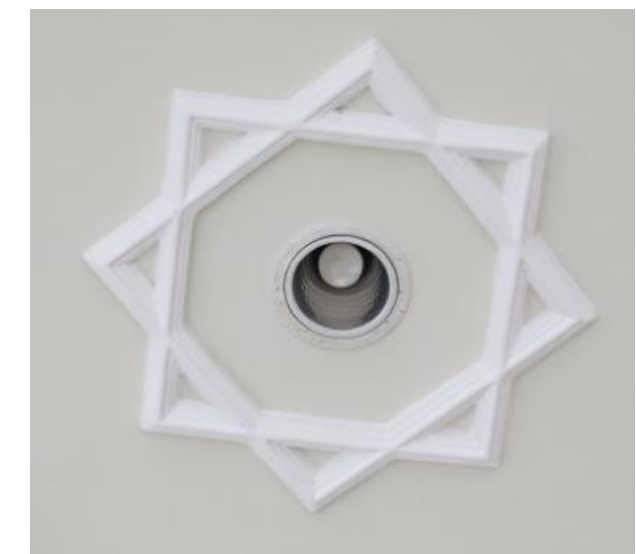

- Finding the area of a shape

Name: lamp decoration

Location: the ceiling of the mosque at the front 


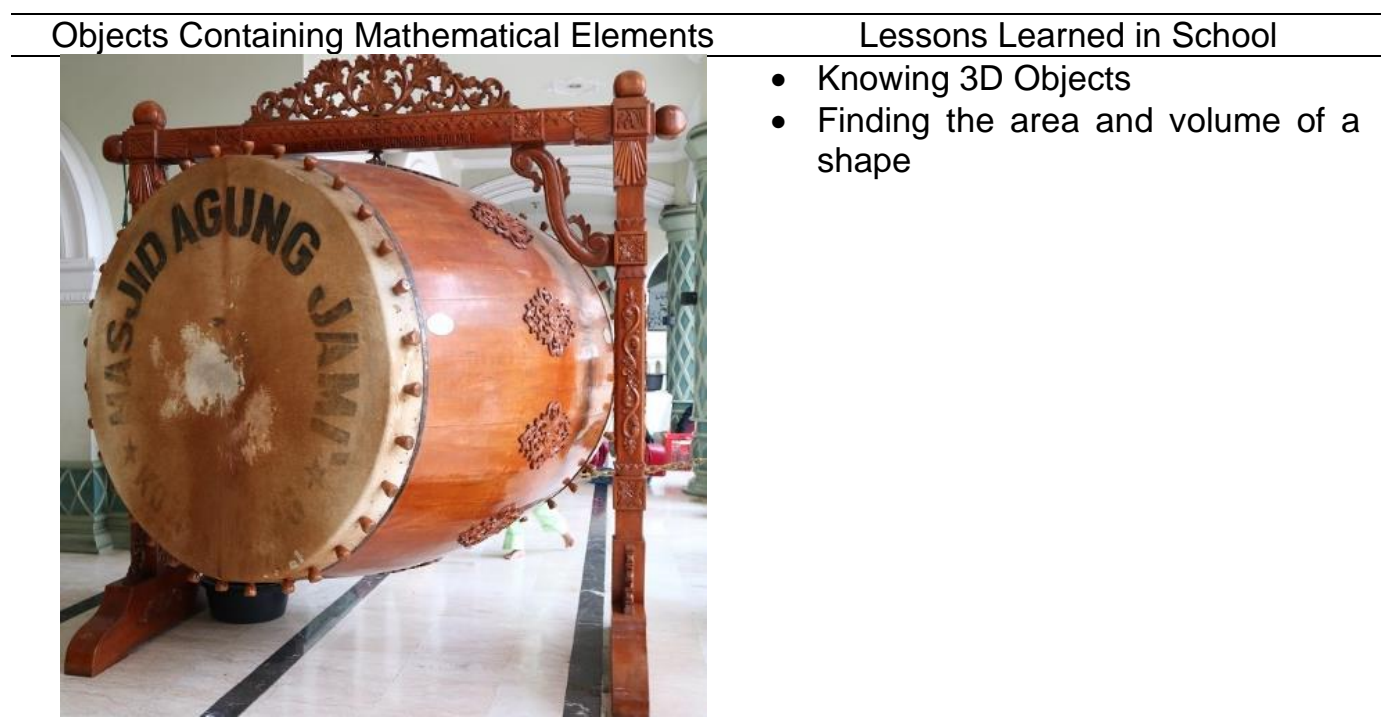

Name: beduk

Location: the front of the mosque

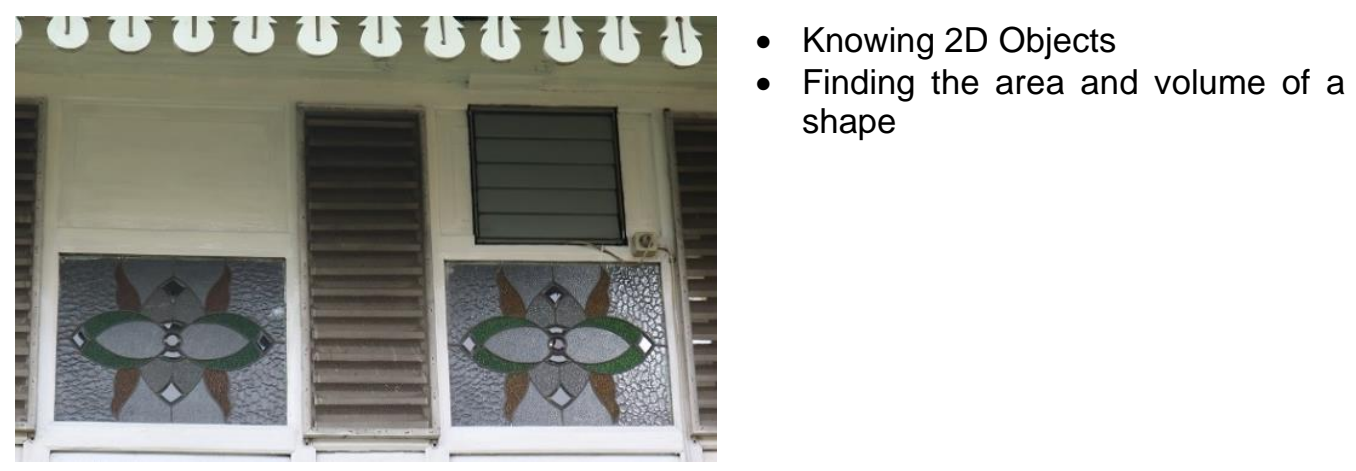

Name: mosque window

Location: outer roof of the mosque

From the observations above, several two-dimensional and three-dimensional geometric shapes were obtained. These include rectangles, semi circles, and cylinders. The number of geometric shapes found in the mosque building is in accordance with previous studies which state that there are mathematical concepts in the Jami' Baitul Amien Jember mosque building (Yudianto et al., 2021) and also in the Jamik mosque in Bengkulu City (Lusiana et al., 2019).

Some geometric shapes obtained in the Jami' Malang mosque building can be used as teaching materials for elementary school students in learning about the concept of geometric shapes. In research Puspitasari (2013) stated that the use of concrete objects in learning geometry affects students' mathematical understanding. The more use of concrete objects such as geometric shapes found in mosque buildings, the students' mathematical understanding will also increase.

\section{Students' Mathematical Problem Solving Ability}

The experiment was conducted by the researcher on 20 elementary school students by giving a pre-test and post-test about problem solving related to the ethnomathematics of the Agung Jami' Malang Mosque. Data collection was carried out before being given a lesson on ethnomathematics 
about the concept of geometric shapes. Pre-test results obtained as much as $75 \%$ working on the questions given.

Furthermore, students were given treatment in the form of introducing the concept of geometric shapes by introducing the shapes found in the Agung Jami' Malang Mosque. then students are given problem solving problems related to the concept of building space. Post-test results obtained as many as $90 \%$ of students are able to work on the questions that have been given.

From the results of the pre-test and post-test conducted, there was an increase in students who succeeded in solving problems by $15 \%$. It can be said that there is an increase in the number of students who are able to overcome problems because they are given learning about ethnomathematics related to the Agung Jami' Malang Mosque. In accordance with research conducted by Kusuma et al., (2019) which states that ethnomathematics is able to improve external mathematical connections and student activity. Other research also states that ethnomathematics can help improve students' problem solving abilities (Cahyadi et al., 2020).

\section{CONCLUSION}

Based on the results of the research that has been done, the ethnomathematics found in the Agun Jami' Malang Mosque includes several geometric shapes such as rectangles, tubes, and semi circles. The results of the students' pre-test and post-test showed an increase in student learning outcomes in solving mathematical problem solving problems. For further research, it is expected to be able to develop the ethnomathematics contained in the Jami' Malang Grand Mosque into a learning module that can be used by students in the learning process.

\section{REFERENCES}

Amir, M. F. (2015). Pengaruh Pembelajaran Kontekstual Terhadap Kemampuan Pemecahan Masalah Matematika Siswa Sekolah Dasar. Prosiding Seminar Nasional Pendidikan, 34-42.

Arifin, S., Zulkardi, Z., \& Darmawijoyo, D. (2010). Kemampuan Penalaran Dan Koneksi Matematis Dalam Pembelajaran Matematika Dengan Problem Solving. Jurnal Pendidikan Matematika, 4(2), 58-66.

Balley, R. W. (1989). human performance engineering. new jersey.

Cahyadi, W., Faradisa, M., Cayani, S., \& Syafri, F. S. (2020). Etnomatematika untuk Meningkatkan Kemampuan Pemecahan Masalah Matematis Siswa. Jurnal Arithmetic: Academic Journal Of Math, 02(01), 99-110.

Hadi, S., \& Radiyatul, R. (2014). Metode Pemecahan Masalah Menurut Polya untuk Mengembangkan Kemampuan Siswa dalam Pemecahan Masalah Matematis di Sekolah Menengah Pertama. EDU-MAT: Jurnal Pendidikan Matematika, 2(1), 53-61. https://doi.org/10.20527/edumat.v2i1.603

Hairunnizam Wahid, Nor Ghani Md Nor, Jaafar Ahmad, \& Sanep Ahmad. (2009). Masjid dan Pembentukan Modal Sosial: Apakah Faktor Penentu Aktivism Masjid? Prosiding Bengkel Penyelidikan Gunaan Dalam Ekonomi Islam. ISBN 978-983-3198-.

Kusuma, D. A., Suryadi, D., \& Dahlan, J. A. (2019). Improving external mathematical connections and students' activity using ethnomathematics. Journal of Physics: Conference Series, 1157(3). https://doi.org/10.1088/1742-6596/1157/3/032120

Lusiana, D., Afriani, N. H., Ardy, H., \& Widada, W. (2019). Eksplorasi Etnomatematika

20 Muhammad H. Asnawi, Hurriyatul Annisa, Moh. M. Ulum, Nur L. Arofah, and Novita E. Hendrawti Ethnomathematic Exploration at Agung Jami' Malang Mosque In Improving Students' Mathematic Problem Solving Skill 
Pada Masjid Jamik Kota Bengkulu. Jurnal Pendidikan Matematika Raflesia, 04(02), 164-176.

Mahmudi. (n.d.). Sejarah Masjid Agung Jami’ Kota Malang.

Mulyati, T. (2016). Kemampuan Pemecahan Masalah Matematis Siswa Sekolah Dasar. EduHumaniora | Jurnal Pendidikan Dasar Kampus Cibiru. https://doi.org/10.17509/eh.v3i2.2807

Muslim, A. (2004). Manajemen pengelolaan masjid. Jurnal Aplikasi Ilmu-Ilmu Agama, V(2), $105-114$.

Nicole R. Rigelman. (2013). Becoming a Mathematical Problem Solver. Mathematics $\begin{array}{llll}\text { Teaching in } & & \end{array}$ https://doi.org/10.5951/mathteacmiddscho.18.7.0416

Puspitasari, P. (2013). Pengaruh Penggunaan Model Benda Konkrit Terhadap Pemahaman Matematika Siswa Pokok Bahasan Bangun Ruang Kubus Dan Balok. In repositori UIN Syekh NUrjati. Institut Agama Islam Negeri SYekh Nurjati Cirebon.

Ramdlani, S. (2010). Kedudukan dan fungsi masjid agung terhadap alun-alun kota malang. Journal of Islamic Architecture, 1(1).

Sulasmono, B. S. (2017). Problem Solving: Signifikansi, Pengertian, dan Ragamnya. Satya Widya. https://doi.org/10.24246/j.sw.2012.v28.i2.p155-166

Sumarni, S. (2018). School Culture and School Performance. EDUKASI: Jurnal Penelitian Pendidikan Agama Dan Keagamaan. https://doi.org/10.32729/edukasi.v7i3.122

Sumartini, T. S. (2016). Peningkatan Kemampuan Pemecahan Masalah Matematis Siswa melalui Pembelajaran Berbasis Masalah. Jurnal Pendidikan Matematika STKIP Garut.

Turyanto, T., Agustito, D., \& Widodo, S. A. (2019). Think Pair Share With Comic For Mathematical Problem Solving Skills. Formatif: Jurnal Ilmiah Pendidikan MIPA, 9(3).

Vahlia, I., \& Agustina, R. (2017). Perbandingan Hasil Belajar Discovery Learning Berbasis Problem Solving Dan Group Investigation Berbasis Problem Solving Pada Pembelajaran Metode Numerik. AKSIOMA Journal of Mathematics Education, 5(1), 82-93. https://doi.org/10.24127/ajpm.v5i1.469

Wahyuni, A., Aji, A., Tias, W., \& Sani, B. (2013). Peran Etnomatematika dalam Membangun Karakter Bangsa: Penguatan Peran Matematika Dan Pendidikan Matematika Untuk Indonesia Yang Lebih Baik.

Widodo, S. A., Irfan, M., Trisniawati, T., Hidayat, W., Perbowo, K. S., Noto, M. S., \& Prahmana, R. C. I. (2020). Process of algebra problem-solving in formal student. Journal of Physics: Conference Series, 1657(1). https://doi.org/10.1088/17426596/1657/1/012092

Widodo, Sri Adi, Pangesti, A. D., Kuncoro, K. S., \& Arigiyati, T. A. (2020). Thinking Process of Concrete Student in Solving Two-Dimensional Problems. Jurnal Pendidikan $M a, 14(2), 117-128$.

Yudianto, E., Febriyanti, R. A., Sunardi, S., Sugiarti, T., \& Mutrofin, M. (2021). Eksplorasi etnomatematika pada Masjid Jami' Al-Baitul Amien Jember. Ethnomathematics Journal, 2(1), 11-20. https://doi.org/10.21831/ej.v2i1.36329

Yuwono, A. (2016). Problem Solving dalam Pembelajaran Matematika. Pendidikan Matematika, 4(1), 143-156. https://doi.org/doi: 10.5465/amj.2014.0424

Yuwono, A. (2018). Problem Solving Dalam Pembelajaran Matematika. Journal of Hand Therapy, 31(1), 145-146. https://doi.org/10.1016/j.jht.2017.11.008 